\title{
Isolation and characterization of arsenic resistant bacteria from wastewater
}

\author{
Syed Zaghum Abbas ${ }^{1,2}$, Mehwish Riaz², Naseem Ramzan ${ }^{2}$, M. Tariq Zahid ${ }^{2}$, \\ Farah R. Shakoori ${ }^{3}$, Mohd. Rafatullah ${ }^{1}$ \\ ${ }^{1}$ Division of Environmental Technology, School of Industrial Technology, Universiti Sains Malaysia, \\ Penang, Malaysia. \\ ${ }^{2}$ Department of Zoology, Government College University, Lahore, Pakistan. \\ ${ }^{3}$ Department of Microbiology and Molecular Genetics, School of Biological Sciences, \\ University of the Punjab, Lahore, Pakistan.
}

Submitted: December 13, 2013; Approved: April 17, 2014.

\begin{abstract}
The present study proposed the isolation of arsenic resistant bacteria from wastewater. Only three bacterial isolates (MNZ1, MNZ4 and MNZ6) were able to grow in high concentrations of arsenic. The minimum inhibitory concentrations of arsenic against MNZ1, MNZ4 and MNZ6 were 300 $\mathrm{mg} / \mathrm{L}, 300 \mathrm{mg} / \mathrm{L}$ and $370 \mathrm{mg} / \mathrm{L}$ respectively. The isolated strains showed maximum growth at $37^{\circ} \mathrm{C}$ and at $7.0 \mathrm{pH}$ in control but in arsenite stress Luria Bertani broth the bacterial growth is lower than control. All strains were arsenite oxidizing. All strains were biochemically characterized and ribotyping (16S rRNA) was done for the purpose of identification which confirmed that MNZ1 was homologous to Enterobacter sp. while MNZ4 and MNZ6 showed their maximum homology with Klebsiella pneumoniae. The protein profiling of these strains showed in arsenic stressed and non stressed conditions, so no bands of induced proteins appeared in stressed conditions. The bacterial isolates can be exploited for bioremediation of arsenic containing wastes, since they seem to have the potential to oxidize the arsenite (more toxic) into arsenate (less toxic) form.
\end{abstract}

Key words: Arsenite oxidizing bacteria, Bioremediation. Enterobacter sp., Klebsiella pneumoniae.

\section{Introduction}

Non-metal inorganic elements having the characteristics of metals are called metalloids. Arsenic is also included in the category of metalloid that is present in trace amounts in water, soil, rocks, air and all living matter at the concentration of $2 \mathrm{mg} / \mathrm{kg}$ on average (Patel et al., 2007). Arsenic occupies the position in group $15 / \mathrm{V}$ (A) of the periodic table having properties that form alloys with different metals like sulphur, carbon, hydrogen and oxygen. Arsenic can exist in 4 different valency states; -3 (arsine), 0 (elemental arsenic), +3 (arsenite), +5 (arsenate). Mostly arsenic is present in the forms of arsenite (III) and arsenate (V). Arsenic itself is not soluble in water but when it combines with different elements then it has wide solubility in water (Aitio and Becking, 2001). As(III) species are more toxic than $\mathrm{As}(\mathrm{V})$ species. Arsenate species are predominant at moderate and high redox potentials, while arsenite species occur under more reducing conditions. Metal arsenites are much more soluble than the corresponding metal arsenates, and arsenites are adsorbed less by solid phases.

Now-a-days, the contamination of drinking water with arsenic refers a big public health problem in the whole world (Smith et al., 2002). The long term exposure of arsenic causes chronic toxicity. Exposure of arsenic through drinking water for a long time leads to lethal conditions like cancer of skin, digestive system, bladder and lungs. Concentration of arsenic in drinking water more than $50 \mu \mathrm{g} / \mathrm{L}$ raises the risks of lung and bladder cancer and even if the concentration is less than $50 \mu \mathrm{g} / \mathrm{L}$, it may increases the risks of skin cancer (Aksu et al., 2010). Gastrointestinal symptoms due to ingestion of large amount of arsenic include severe vomiting, abdominal pain, fatigue, abnormal heart rhythm, abnormal bruising and destruction of nervous system. It also causes defects in blood circulation and ulti- 
mately leading to death. When not deadly, it breaks up red blood cells in blood circulation, causes less production of blood cells, darkening of skin, enlargement of liver, damage of brain, pins and needle like sensation in hands and feet and loss of ability of sensation in the limbs. Non-cancer effects may also cause by arsenic like diabetes, nervous and immune system problems, reproductive problems and cardiovascular problems including heart disease, stroke and high blood pressure (Tseng, 2004).

Conventional methods for removing metals from industrial effluents are chemical precipitation, chemical oxidation or reduction, ion exchange, filtration, electrochemical treatment, reverse osmosis, membrane technologies and evaporation recovery (Ahluwalia and Goyal, 2007). These processes may be ineffective or extremely expensive especially when the metals in solution are in the range of $1-100 \mathrm{mg} / \mathrm{L}$. Therefore, it is important to develop an innovative, low cost and eco-friendly method for removal of toxic heavy metal ions from the water and wastewater (Lou and Chin, 2008). A wide variety of microorganisms are capable of growth in the presence of heavy metal ions and tolerates high concentrations (Gaballa and Helmann, 2003; Rehman et al., 2007). Anderson and Cook (2004) reported strains of Aeromonas, Exiguobacterium, Acinetobacter, Bacillus and Pseudomonas, that can tolerate high concentrations of arsenic species (up to $100 \mathrm{mM}$ arsenate or up to $20 \mathrm{mM}$ arsenite). Since heavy metals are ubiquitously present in our environment, microorganisms have developed mechanisms to resist the toxic effects of these heavy metals. Several bacteria belonging to the genera Acidithiobacillus, Bacillus, Deinococcus, Desulfitobacterium and Pseudomonas have been reported to be resistant to arsenic (Oremland et al., 2004; Suresh et al., 2004a).

Resistance to arsenic species in both Gram-positive and Gram-negative organisms results from energy-dependent efflux of either arsenate or arsenite from the cell mediated via the ars operon (Tseng, 2007). In E. coli, an ArsAArsB complex functions as a primary arsenite pump (Yoon, 2005). In S. aureus, ArsB alone is sufficient to act as a chemiosmotic secondary transport system for arsenite resistance without the presence of an ArsA ATPase (WolfeSimon et al., 2011). An additional gene, ars $C$, has been shown to encode for an arsenate reductase that mediates reduction of arsenate prior to arsenite efflux (Liao et al., 2011).

The present study deals with the isolation and characterization of arsenic resistant bacteria from a contaminated environment, the ability of the bacteria to oxidize arsenite, and optimization of temperature and $\mathrm{pH}$ for maximum arsenite oxidation.

\section{Material and Methods}

\section{Sample collection and bacterial isolation}

For the isolation of arsenic resistant bacteria, wastewater samples were collected from Kala Shah Kakoo, Pakistan in screw capped sterilized bottles. Some physio-chemical parameters like $\mathrm{pH}$, temperature, dissolved oxygen and arsenic $(\mu \mathrm{g} / \mathrm{mL})$ were measured. About $50 \mu \mathrm{L}$ water samples were spread on Luria Bertani agar plates that contain $10 \mu \mathrm{g} / \mathrm{L}$ of arsenite for the isolation of arsenic resistant bacteria (Shakoori et al., 2010). After $24 \mathrm{~h}$ of incubation at $37^{\circ} \mathrm{C}$ the growth of bacteria was observed. Individual colonies were picked and streaked on Luria Bertani agar medium containing $20 \mathrm{mg} / \mathrm{L}$ of arsenite. The Luria Bertani agar was prepared by mixing $5 \mathrm{~g}$ of sodium chloride, $5 \mathrm{~g}$ of yeast extract, $10 \mathrm{~g}$ of trypton and 17 to $19 \mathrm{~g}$ of agar per $1000 \mathrm{~mL}$ of water, $\mathrm{pH}$ of medium was adjusted between 7.0 and 7.2. After mixing $100 \mathrm{~mL}$ medium was taken in a flask and covered with cotton plug. The medium was autoclaved at $15 \mathrm{lb}$ per inch square pressure $121^{\circ} \mathrm{C}$ for $15 \mathrm{~min}$. After $24 \mathrm{~h}$ the growth of bacterial colonies was observed at $37{ }^{\circ} \mathrm{C}$ of incubation. The effects of arsenite on bacterial strains growth was checked in acetate minimal medium which contained $\mathrm{g} / \mathrm{L}: 0.5 \mathrm{~g}$ yeast extract, $0.2 \mathrm{~g}$ magnesium sulphate $\left(\mathrm{MgSO}_{4}\right), 5.0 \mathrm{~g}$ sodium acetate, 0.001 $\mathrm{g}$ ferric sulphate $\left(\mathrm{FeSO}_{4}\right), 0.001 \mathrm{~g}$ calcium chloride $\left(\mathrm{CaCl}_{2}\right), 0.5 \mathrm{~g}$ potassium phosphate $\left(\mathrm{KH}_{2} \mathrm{PO}_{4}\right)$ and $1.0 \mathrm{~g}$ ammonium chloride $\left(\mathrm{NH}_{4} \mathrm{Cl}\right)$ in $1000 \mathrm{~mL}$ of distilled water. After mixing thoroughly $5 \mathrm{~mL}$ medium was taken in each test tube and autoclaved at $121^{\circ} \mathrm{C}, 15 \mathrm{lb}$ per inch square pressure for 15-18 min. After bacterial inoculation in acetate minimal medium test tubes were kept in shaker incubator at $37^{\circ} \mathrm{C}$ for $24 \mathrm{~h}$.

\section{Minimum inhibitory concentration of bacterial strains}

For the determination of minimum inhibitory concentration of the bacterial strains $5 \mathrm{~mL}$ of acetate minimal medium was added in each test tube and different concentrations of arsenite were added from 30 to $370 \mathrm{mg} / \mathrm{L}$. They were inoculated and incubated at $37^{\circ} \mathrm{C}$ for $24 \mathrm{~h}$ in shaking incubator. Optical density of each bacterial isolates was estimated by spectrophotometer. The same process was repeated on Luria Bertani agar plates and noted the growth of bacterial colonies at different arsenic concentrations. Basically on the agar plate bacteria can only access the nutrients underneath, and are therefore only able to grow horizontally secondly in plate method surface to volume ratio of bacteria against arsenic is very low, while in the broth they are surrounded by nutrients and surface to volume ratio also very high. Due to this reason broth considered as standard method because the minimum inhibitory concentration of bacteria in broth is very low than agar. 


\section{Identification of bacterial isolates}

For morphological identification of bacterial isolates different tests were performed like gram staining, acid fast staining, endospore staining and motility test. For biochemical characterization of bacterial strains some tests like catalase, urease, carbohydrate, gelatin hydrolysis, citrate agar tests were carried out. Some specific tests were performed like Methyl-Red Voges Proskaure test, MacConkey agar test, blood agar test, chocolate-agar test for species level characterization of bacterial isolates (Brown, 2009). For molecular characterization, genomic DNA was purified by using GenElute kit. So with the help of polymerase chain reaction (PCR) the $16 \mathrm{~S}$ rRNA was amplified by using $16 \mathrm{~S}$ rRNA primers (UNI-27F; 5'-AAACTC-AAATGAATTGACGG-3', and UNI-1492R; 5'-ACGGGCGGTGTGTAC-3') (Kim et al., 2012). The PCR was completed with an initial denaturation step at $94{ }^{\circ} \mathrm{C}$ for $5 \mathrm{~min}$, followed by 35 cycles with the denaturation at $94{ }^{\circ} \mathrm{C}$, annealing at $52{ }^{\circ} \mathrm{C}$ and elongation at $72{ }^{\circ} \mathrm{C}$ for $30 \mathrm{~s}, 40 \mathrm{~s}$ and $30 \mathrm{~s}$ respectively. Final extension was given at $72{ }^{\circ} \mathrm{C}$ for $10 \mathrm{~min}$. After amplification the $16 \mathrm{~S}$ rRNA product by using PCR kit (Fermentas Co, Germany) was compared with known sequences in the GenBank database (The GenBank data base an open access, annotated collection of all publicly available nucleotide sequences and their protein translations) to identify most related species.

\section{Determination of growth curves}

For the determination of these bacterial strains growth curves with and without arsenite stress $100 \mathrm{~mL}$ Luria Bertani broth was prepared in conical flask and steam sterilized. Experiments were performed in triplicates. Medium was inoculated with bacterial culture in log phase and incubated for $24 \mathrm{~h}$ at $37^{\circ} \mathrm{C}$ in shaking incubator. One $\mathrm{mL}$ of sample was drawn in a cuvette with the help of micropipette in laminar air flow after two hour. Optical density was taken at $600 \mathrm{~nm}$. Growth curves were plotted by taking optical density on $\mathrm{Y}$-axis and incubation time on $\mathrm{X}$-axis.

\section{Determination of optimum $\mathrm{pH}$ and temperature}

About $20 \mathrm{~mL}$ of sterilized Luria Bertani broth were taken in $50 \mathrm{~mL}$ flasks. The $\mathrm{pH}$ range of medium was adjusted from 4.0 to 10.0. Each $\mathrm{pH}$ was taken in triplicates without and with arsenite stress $(10 \mu \mathrm{g} / \mathrm{L})$. They were then inoculated with $10 \mu \mathrm{L}$ of fresh culture of each bacterial isolates and incubated at $37{ }^{\circ} \mathrm{C}$ in shaking incubator. After $24 \mathrm{~h}$ optical density was noted in spectrophotometer at $600 \mathrm{~nm}$. A graph was plotted between optical density along $\mathrm{Y}$-axis and $\mathrm{pH}$ along $\mathrm{X}$-axis. The optimum $\mathrm{pH}$ was of each strain was determined by graph. For the temperature measurement steam sterilized $50 \mathrm{~mL}$ Luria Bertani broth was prepared in $100 \mathrm{~mL}$ conical flasks for the determination of optimum temperature. After inoculation with the isolates these flasks without and with arsenite stress $(10 \mu \mathrm{g} / \mathrm{L})$ were kept at different temperatures range from $15^{\circ} \mathrm{C}$ to $40{ }^{\circ} \mathrm{C}$ for $24 \mathrm{~h}$. Experiments were conducted in triplicate, Optical density of each strain was noted and graphs were plotted taking optimum density along $\mathrm{Y}$-axis and temperature along $\mathrm{X}$-axis.

\section{Protein profiling}

In conical flasks, $20 \mathrm{~mL}$ Luria Bertani broth were taken in triplicates and steam sterilized. Bacterial isolates were stressed with different concentrations of arsenite from 50 to $350 \mu \mathrm{g} / \mathrm{L}$, incubated for $24 \mathrm{~h}$ at $37^{\circ} \mathrm{C}$ in shaking incubator and harvest the cells by centrifugation. Pellet was dissolved in $100 \mu \mathrm{L}$ of $1 \mathrm{X}$ loading dye then heat shock was given for $5 \mathrm{~min}$, eppendorf was shifted on ice for $2 \mathrm{~min}$, and then was centrifuged at $12000 \mathrm{rpm}$ for $10 \mathrm{~min}$. Supernatant was transferred to a new eppendorf, then final centrifugation was done at $12000 \mathrm{rpm}$ for $10 \mathrm{~min}$ and supernatant was shifted to a new eppendorf. Initially gel was run at $40 \mathrm{mV}$ after stake formation the voltage was increased to $80 \mathrm{mV}$.

\section{Results and Discussion}

\section{Physio-chemical characteristics of bacterial isolates}

Industrial wastewater samples were collected from Kala Shah Kakoo near Lahore, Pakistan. Sample 1 and Sample 2 collected from effluents of Ittehad Chemicals and sample 3 was collected from Ravi Chemical complex. The temperature of these samples ranged from $28{ }^{\circ} \mathrm{C}$ to $31^{\circ} \mathrm{C}, \mathrm{pH}$ ranged from 5.0 to 7.0 , dissolved oxygen ranged from $0.45 \pm 0.01$ to $1.30 \pm 0.03 \mathrm{mg} / \mathrm{L}$, and arsenic ranged from $1.10 \pm 0.04$ and $1.90 \pm 0.03 \mu \mathrm{g} / \mathrm{mL}$.

\section{Minimum inhibitory concentration of bacterial strains}

The effect of different concentrations of arsenic on the growth of isolates was determined by incubating $100 \mathrm{~mL}$ of acetate minimal medium inoculated with $200 \mu \mathrm{L}$ of overnight culture for $24 \mathrm{~h}$ and then optimum density determined at $600 \mathrm{~nm}$. The minimum inhibitory concentration of arsenite against bacteria isolated from industrial wastewater was checked. The minimal inhibitory concentration of arsenite against Enterobacter sp., Klebsiella pneumoniae 1 and Klebsiella pneumoniae 2 was $300 \mathrm{mg} / \mathrm{L}$, $300 \mathrm{mg} / \mathrm{L}$ and $370 \mathrm{mg} / \mathrm{L}$ respectively as shown in Figure 1.

\section{Characterization of bacterial isolates}

The sample 1 and sample 2 bacterial isolates were cocci and Gram negative but bacterial isolates of sample 3 were rod shape and Gram positive. Bacterial isolates were motile, spore forming, aerobic, microaerophilic and acid fast. They form round and off white colonies. The bacterial isolates had ability to degrade hydrogen peroxide with the help of catalase enzyme. All stains were capable to convert 


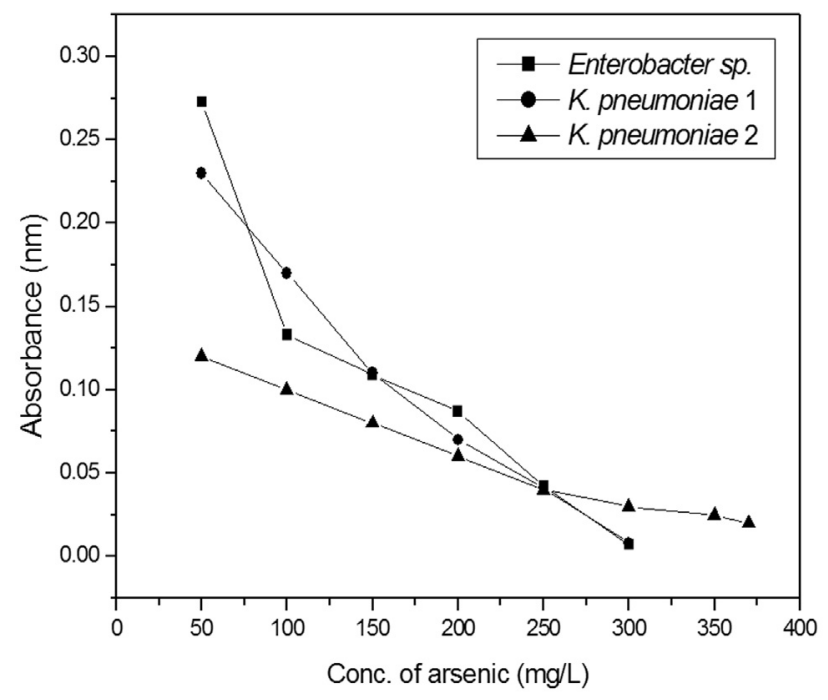

Figure 1 - Effect of different concentrations of arsenic on the growth of Enterobacter sp., Klebsiella pneumoniae 1 and Klebsiella pneumoniae 2.

urea into ammonia by urease enzyme. Enterobacter sp. was gelatinase producing strain while Klebsiella pneumoniae 1 and Klebsiella pneumoniae 2 could not produce gelatinase. All strains could ferment the glucose. All strains could use citrate as carbon source. All strains were non-pathogenic and are fastidious. The pink colonies of all isolates appeared on Mac-Conkay agar. The biochemical tests for MNZ1 showed that this isolate belonged to genus Enterobacter sp. while biochemical test for MNZ4 and MNZ6 showed them belonged to genus Klebsiella as shown in Table 1. A conserved region of $16 \mathrm{~S}$ rRNA gene of bacterial isolates were amplified and sequenced. After sequencing, the $16 \mathrm{~S}$ rRNA gene of MNZ1 was $96 \%$ homologous to Enterobacter sp., MNZ4 was 95\% homologous to Klebsiella pneumoniae 1 and MNZ6 was $97 \%$ homologous to Klebsiella pneumoniae 2.

\section{Growth curves with and without arsenite stress}

The lag phase of Enterobacter $\underline{\mathrm{s}}$., during arsenite stress condition extended from $0-4 \mathrm{~h}$ as compared to control which was prolonged to $0-2 \mathrm{~h}$. The exponential phase was similar to each other but stationary phase in non-stressed condition was longer than stressed condition. The Klebsiella pneumoniae 1 and Klebsiella pneumoniae 2 showed only difference in lag phase which was more extended in stress condition than control. The lag phase, which was extended in the arsenic-stress medium normally occurs in the beginning of inoculation because the arsenic has toxic effect on the cell wall of bacteria and damage it so bacteria expands lot of energy to repair it so little growth occurs as the bacteria are becoming 'acclimatized' to the new environmental conditions (Gikas et al., 2009). The exponential and stationary phases were similar as shown in Figure 2.

\section{Determination of optimum $\mathrm{pH}$ and temperature}

To check the effect of $\mathrm{pH}$ the bacterial isolates with and without arsenite stress was grown at arrange of $\mathrm{pH}$ i.e. 4.0-10.0. The results showed that optimum $\mathrm{pH}$ in control

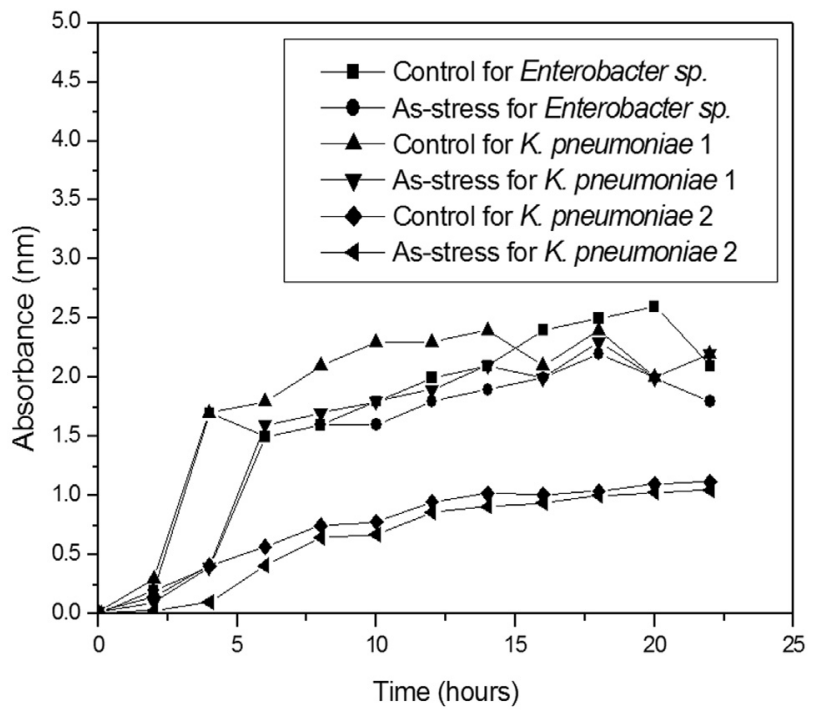

Figure 2 - Effect of arsenic on the growth of Enterobacter sp., Klebsiella pneumoniae 1 and Klebsiella pneumonia 2.

Table 1 - Biochemical characteristics of bacterial isolates.

\begin{tabular}{|c|c|c|c|}
\hline Biochemical tests & Enterobacter sp. & K. pneumoniae 1 & K. pneumoniae 2 \\
\hline Catalase test & positive & positive & positive \\
\hline Urease test & positive & positive & positive \\
\hline Gelatin-hydrolysis test & positive & negative & negative \\
\hline Carbohydrate fermentation test & positive & positive & positive \\
\hline MRVP-test & negative & negative & negative \\
\hline Citrate test & positive & positive & positive \\
\hline Blood agar test & negative & negative & negative \\
\hline Chocolate agar test & positive & positive & positive \\
\hline Mac-Conkay agar test & positive & positive & positive \\
\hline
\end{tabular}


medium for Enterobacter sp. (MNZ1) growth was 7.0. The bacteria could not grow at acidic and basic $\mathrm{pH}$. The Klebsiella pneumoniae 1 (MNZ4) could tolerate acidic $\mathrm{pH}$ and sensitive to basic $\mathrm{pH}$ and its growth was maximum at $\mathrm{pH} 7.0$ in non-stressed medium. The Klebsiella pneumoniae 2 (MNZ6) could grow at basic $\mathrm{pH}$ but not tolerate the acidic $\mathrm{pH}$ and optimum $\mathrm{pH}$ for its growth was 7.0 as shown in Figure 3. To determine the optimum temperature of bacterial isolates in control and stressed condition they were grown at different ranges of temperature i.e. $15-40{ }^{\circ} \mathrm{C}$. The optimum temperature for growth of these strains was $37^{\circ} \mathrm{C}$ in the control medium. The bacterial isolates are normally sensitive to change in $\mathrm{pH}$ than temperature as shown in Figure 4. The maximum $\mathrm{pH}$ and temperature in arsenite-stress medium also same as control but the optical density of these strains is little bit low because arsenite act as a toxic substance and stop the bacterial growth in the earlier hours than after adjusting to the media environment bacteria starts to grow (Lomax et al., 2012).

\section{Verification of transforming ability of the strains}

$\mathrm{AgNO}_{3}$ method was used to verify the transforming ability of bacterial isolates. Bacterial isolates were streaked on Luria Bertani agar plate containing $10 \mathrm{mg} / \mathrm{L}$ of arsenite. Plates were incubated at $37^{\circ} \mathrm{C}$ for $48 \mathrm{~h}$ and were flooded with $0.1 \mathrm{M} \mathrm{AgNO}_{3}$ solution (Valenzuela et al., 2009). The appearance of bright yellow precipitates indicated the presence of arsenite which shows that arsenate reducing bacteria while the presence of arsenate was revealed by brownish precipitates which shows the arsenite oxidizing bacteria. The agar plates were flooded with $0.1 \mathrm{M} \mathrm{AgNO}_{3}$. A brownish precipitate indicated that arsenate present in the medium so these isolates were arsenite oxidizing bacteria as shown in Figure 5.

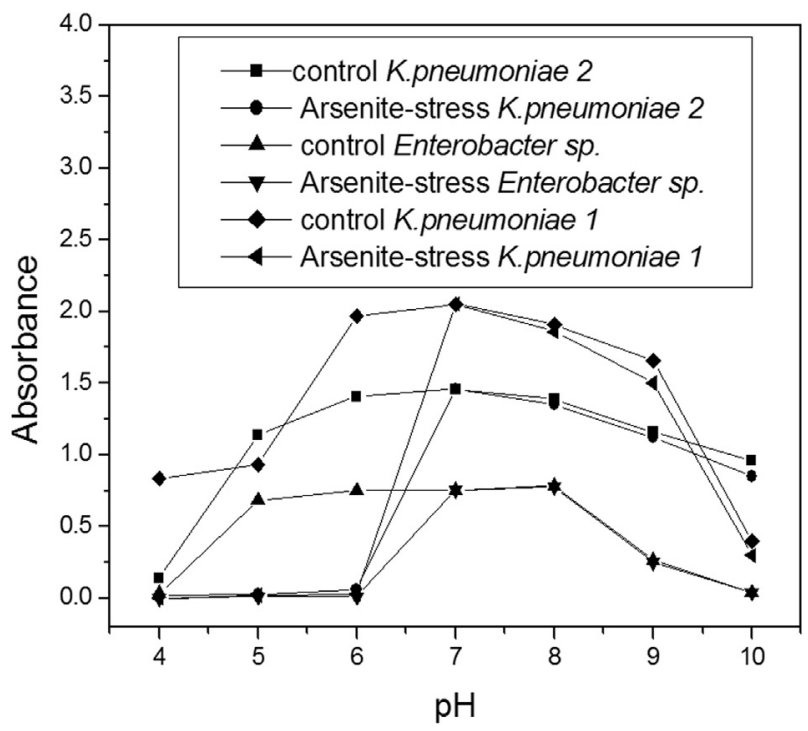

Figure 3 - Effect of $\mathrm{pH}$ on the growth of Enterobacter sp., Klebsiella pneumoniae 1 and Klebsiella pneumoniae 2.

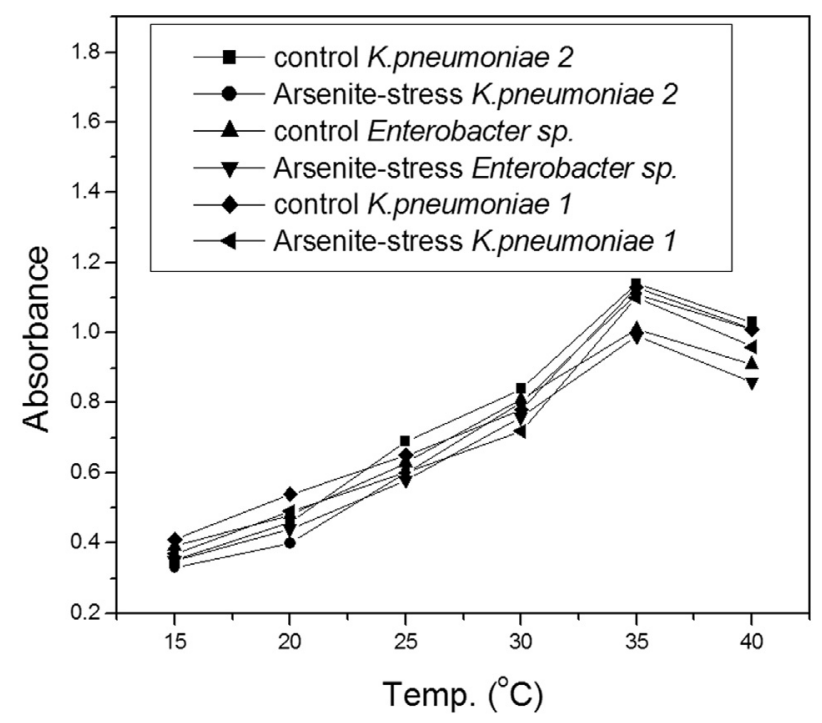

Figure 4 - Effect of temperature on the growth of Enterobacter sp., Klebsiella pneumoniae 1 and Klebsiella pneumoniae 2.

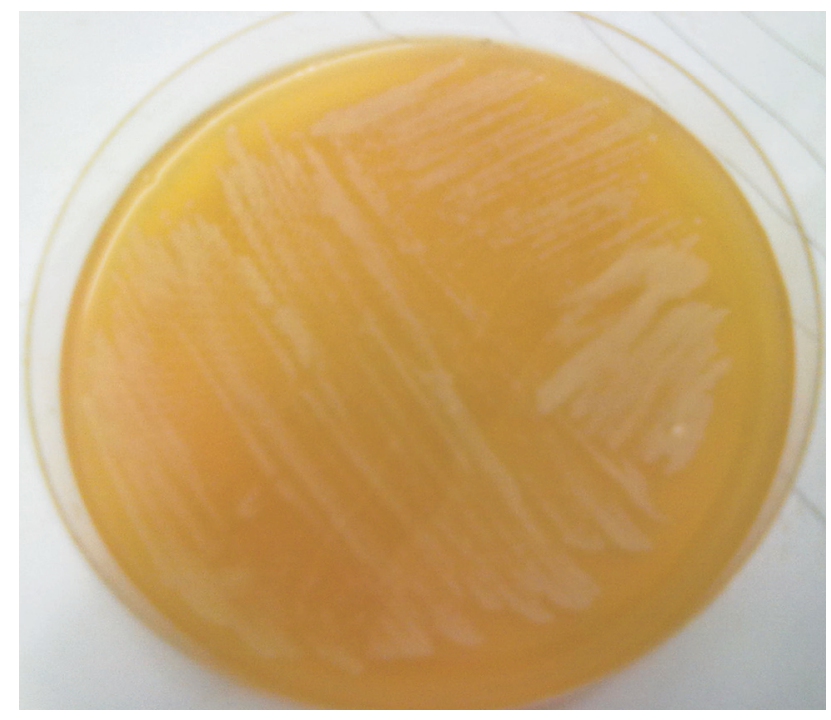

Figure 5 - The presence of arsenate showing on LB agar plates.

\section{Protein profiling}

To study the protein profile of bacteria under stressed and non-stressed conditions, total cell proteins of bacteria were isolated after 2, 4 and $6 \mathrm{~h}$ of metal exposure. Metal stress to bacteria was given after their optical density reached to 0.3 indicating that bacteria have entered into log phase. In SDS-PAGE of stressed organisms did not indicate any new protein band (Chovanová et al., 2004; Lacerda et al., 2007). This indicated that the arsenite resistance proteins in bacteria were constitutive proteins and they expressed in the non stressed conditions as shown in Figure 6.

A large number of microorganisms are involved in the biogeochemical cycle of arsenic. Different kinds of 


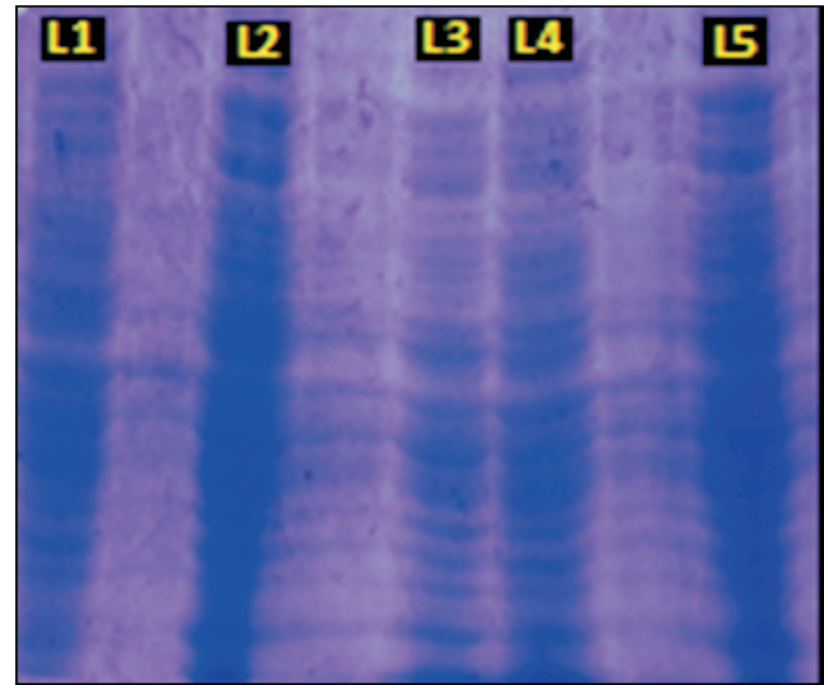

Figure 6 - Lane 1, Lane 2 and Lane 5 showing the protein bands of non-stressed bacterial culture of 2, 4 and $6 \mathrm{~h}$, while Lane 3 and Lane 4 indicating the protein bands of arsenic stressed bacterial culture.

mechanisms like oxidation, reduction, methylation, precipitation, biosorption through cell biomasss, active cell transport, entrapment by cellular capsules and production of induced proteins are present in the bacteria, mosses, ciliates and algae, fungi, higher plants and macrophytes for the removal of heavy metals from aqueous solution (Rehman et al., 2007).

Mostly bacteria present in industrial wastewater are the members of genera Bacillus, Dienococcus, Pseudomonas, Acidthiobacillus, and Desulfitobacterium in which resistance against arsenic have been reported (Suresh et al., 2004b). In the present study three strains were isolated from industrial waste water which belongs to genus Enterobacter sp. and Klebsiella. The reduction of arsenate to arsenite is also reported in many bacteria. The cytoplasmic arsenate reductase helps the cell in intracellular defense and in most cells this enzyme is encoded by arsC located in ars operon. Three unrelated sequences of arsC are found that have same function. (i) A group of thioredoxin coupled arsenate reductase initially present in gram positive bacteria but recently found in gram negative bacteria, (ii) Glutaredoxin dependent arsenate reductase in the yeast and (iii) Glutaredoxin-gluthathione coupled enzyme that is found in association with arsenite reductase and respiratory arsenate reductase of Shewanella. ArsC encoded protein is monomeric contains 135 amino acid residue consist 3 essential cysteine residue (Silver and Phung, 2005; Mukhopadhyay et al., 2002). Location of first cysteine residue is at position 11 from N-terminus of arsC protein, glutathione and glutaredoxin provide other two cysteine residue (Mukhopadhyay et al., 2002; Oremland et al., 2002). No strain is involved in arsenate reduction mean these cannot convert arsenate into arsenite which is hundred times more toxic than arsenate (Campos et al., 2009).
So this is not eco-friendly detoxification mechanism and not significantly used by microorganisms for the removal of arsenic from industrial waste water. Industrial effluents do not only contain heavy metals but they are also loaded with number of organic compounds like carbohydrates, urea, gelatin, sulphides, food, pigments of paints, pesticides and poultry feedlot which also have a role in environmental pollution. These isolates are also able to use these by products as an organic source. As a result these organic compounds are also detoxified.

\section{Conclusions}

The arsenic resistant bacteria isolated in this study were Enterobacter sp. and Klebsiella pneumoniae based on phylogenetic analysis of $16 \mathrm{~S}$ rDNA sequence. The Enterobacter sp. (MNZ1), Klebsiella pneumoniae 1 (MNZ4) and Klebsiella pneumonia 2 (MNZ6) are highly resistant against arsenic metal and survive in the presence of high concentration of arsenic. The minimum inhibitory concentration of arsenite was considerable at temperature $37^{\circ} \mathrm{C}$. he minimum inhibitory concentration of As (III) against Enterobacter sp., Klebsiella pneumoniae 1 was $300 \mathrm{mg} / \mathrm{L}$, while against Klebsiella pneumoniae 2 was 370 $\mathrm{mg} / \mathrm{L}$. The lag phase of Enterobacter sp. was longer in As (III) stress condition than control while log and exponential phase are similar in both conditions but duration of stationary phase is more in control. In Klebsiella pneumoniae 1 (MNZ4) and Klebsiella pneumoniae 2 (MNZ6) only differences in lag phase, other phases are similar in both arsenite stress and non-stress condition. The bacterial isolates are arsenite oxidizing bacteria so they convert more toxic form of arsenic (arsenite) into less toxic form (arsenate). So according to these results bacterial isolates have evolved mechanisms to tolerate high concentration of arsenic or to regulate arsenic resistant genes. The results from protein profiling showed that no induced proteins were expressed in arsenic stress conditions. These bacteria can be used for the bioremediation of arsenic. In future these isolates may be helpful in the bioremediation of industrial waste especially with reference to heavy metals.

\section{Acknowledgement}

The authors would like to express their appreciations to Government College University, Lahore and Universiti Sains Malaysia (Short term grant; 304/PTEKIND/6312118 ) for the support and research facilities for this project.

\section{References}

Ahluwalia SS, Goyal D (2007) Microbial and plant derived biomass for removal of heavy metals from wastewater. Bioresour Technol 98:2243-2257.

Aitio A, Becking G (2001) Arsenic and arsenic compounds. Environmental Health Criteria 224, World Health Organization, Geneva. 
Aksu A, Balkis N, Ersan MS, Muftuoglu AE, Apak R (2010) Biogeochemical cycle of arsenic and calculating the enrichment factor by using Li element. Environ Geochem Health 32:303-306.

Anderson CR, Cook GM (2004) Isolation and characterization of arsenate-reducing bacteria from arsenic-contaminated sites in New Zealand. Curr Microbiol 48:341-347.

Brown AE (2009) Benson's Microbiological Applications Laboratory Manual in General Microbiology. McGraw-Hill Higher Education, New York.

Campos VL, Escalante G, Yanez J, Zaror CA, Mondaca MA (2009) Isolation of arsenite-oxidizing bacteria from a natural biofilm associated to volcanic rocks of Atacama Desert, Chile. J Basic Microbiol 49:93-97.

Chovanová K, Sládeková D, Kmet V, Proksova M, Harichová J, Puskarova A, Polek B, Ferianc P (2004) Identification and characterization of eight cadmium resistant bacterial isolates from a cadmium-contaminated sewage sludge. Biologia 59:817-827.

Gaballa A, Helmann JD (2003) Bacillus subtilis CPx-type ATPases: characterization of $\mathrm{Cd}, \mathrm{Zn}, \mathrm{Co}$ and $\mathrm{Cu}$ efflux systems. Biometals 16:497-505.

Gikas P, Sengor S, Ginn T, Moberly J, Peyton B (2009) The effects of heavy metals and temperature on microbial growth and lag. Global NEST Journal 11:325-332.

Kim OS, Cho YJ, Lee K, Yoon SH, Kim M, Na H, Park SC, Jeon YS, Lee JH, Yi H (2012) Introducing EzTaxon-e: a prokaryotic 16S rRNA gene sequence database with phylotypes that represent uncultured species. Int J Syst Evol Microbiol 62:716-721.

Lacerda M, Choe H, Reardon F (2007) Metaproteomic analysis of a bacterial community response to cadmium exposure. J Proteome Res 6:1145-1152.

Liao VHC, Chu YJ, Su YC, Hsiao SY, Wei CC, Liu CW, Liao CM, Shen WC, Chang FJ (2011) Arsenite-oxidizing and arsenate-reducing bacteria associated with arsenic-rich groundwater in Taiwan. J Contam Hydrol 123:20-29.

Lomax C, Liu WJ, Wu L, Xue K, Xiong J, Zhou J, McGrath SP, Meharg AA, Miller AJ, Zhao FJ (2012) Methylated arsenic species in plants originate from soil microorganisms. New Phytologist 193:665-672.

Lou JC, Lin YC (2008) Assessing the feasibility of wastewater recycling and treatment efficiency of wastewater treatment units. Environ Monit Assess 137:471-479.

Mukhopadhyay R, RosenBP, Phung LT, Silver S (2002) Microbial arsenic: from geocycles to genes and enzymes. FEMS Microbiol Rev 26:311-325.
Oremland RS, Newman DK, Kail BW, Stolz JF (2002) Bacterial respiration of arsenate and its significance in the environment. In: W. Frankenberger (ed) Environmental Chemistry of Arsenic. Marcel Dekker, New York, pp 273-296.

Oremland RS, Stolz JF, Hollibaugh JT (2004) The microbial arsenic cycle in Mono Lake, California. FEMS Microbiol Ecol 48:15-27.

Patel PC, GoulhenF, Boothman C, Gault AG, Charnock JM, Kalia K, Lloyd JR (2007) Arsenate detoxification in a Pseudomonad hypertolerant to arsenic. Arch Microbiol 187:171183.

Rehman A, Ali A, Muneer B, Shakoori A (2007) Resistance and biosorption of mercury by bacteria isolated from industrial effluents. Pak J Zool 39:137-150.

Shakoori FR, Aziz I, Rehman A, Shakoori A (2010) Isolation and characterization of arsenic reducing bacteria from industrial effluents and their potential use in bioremediation of wastewater. Pak J Zool 42:331-338.

Silver S, Phung LT (2005) A bacterial view of the periodic table: genes and proteins for toxic inorganic ions. J Ind Microbiol. Biotechnol 32:587-605.

Smith AH, Lopipero PA, Bates MN, Steinmaus CM (2002) Arsenic epidemiology and drinking water standards. Science 296:2145-2146.

Suresh K, Reddy G, Sengupta S, Shivaji S (2004a) Deinococcus indicus sp. nov., an arsenic-resistant bacterium from an aquifer in West Bengal, India. Int J Syst Evol Micr 54:457461.

Tseng CH (2004) The potential biological mechanisms of arsenic-induced diabetes mellitus. Toxicol Appl Pharmacol 197:67-83.

Tseng CH (2007) Arsenic methylation, urinary arsenic metabolites and human diseases: current perspective. J Environ Sci Health Part C 25:1-22.

Valenzuela C, Campos V, Yañez J, Zaror C, Mondaca M (2009) Isolation of arsenite-oxidizing bacteria from arsenicenriched sediments from Camarones River, Northern Chile. B. Environ Contam Tox 82: 593-596.

Wolfe-Simon F, Blum JS, Kulp TR, Gordon GW, Hoeft SE, Pett-Ridge J, Stolz JF, Webb SM, Weber PK, Davies PC (2011) A bacterium that can grow by using arsenic instead of phosphorus. Science 332:1163-1166.

Yoon KP (2005) Stabilities of artificially transconjugated plasmids for the bioremediation of cocontaminated sites. J Microbiol 43:196-203.

All the content of the journal, except where otherwise noted, is licensed under a Creative Commons License CC BY-NC. 